\title{
Chronic Crayfish Plague Infection and Eroded Swimmeret Syndrome in Lake Saimaa (Finland) Signal Crayfish
}

\author{
Japo Jussila, ${ }^{1, *}$ Vesa Tittinen $^{2}$ and Lennart Edsman ${ }^{3}$ \\ ${ }^{1}$ Department of Environmental and Biological Sciences, University of Eastern Finland, P.O.Box 1627, 70210 Kuopio, Suomi-Finland. \\ *Corresponding Author._-japo.jussila@uef.fi \\ ${ }^{2}$ South Karelian Fisheries Advisory Center, Hietakallionkatu 2, 53850 Lappeenranta, Suomi-Finland. e-mail: vesa.tiitinen@ekkalatalouskeskus.fi \\ ${ }^{3}$ Department of Aquatic Resources, Swedish University of Agricultural Sciences, Stångholmsvägen 2, 17893 Drottningholm, Sweden. \\ e-mail: lennartedsman@slu.se
}

A B S T R A C T

We present data and results from a 9-year survey $(2009$ - 2017) of the Lake Saimaa signal crayfish population in Finland. This population has a history of chronic infection with Aphanomyces astaci. It has now been discovered that female signal crayfish from Lake Saimaa suffer from various stages of eroded swimmeret syndrome (ESS), and male crayfish also show symptoms of ESS-like trauma (i.e., eroded swimmerets and gonopods). Our data demonstrates the prevalence of $A$. astaci infection, with gross symptoms prevailing throughout the duration of the entire 2009 - 2017 survey, and that prevalence of ESS among female signal crayfish is correlated with the prevalence of $A$. astaci infection in the population. The data shows that an increasing proportion of female crayfish suffer from ESS, and have regenerated swimmerets, however, our observations indicate that partially regenerated swimmerets do not fully function during egg hatching. Based on data and observations during the survey, we speculate that low production levels, as indicated by the low catch per unit effort (CPUE), within the Lake Saimaa signal crayfish population could be related to both high $A$. astaci infection levels and ESS prevalence among females. The former could be causing increasing mortality among adult crayfish and the latter could be lowering Lake Saimaa signal crayfish reproductive output.

Copyright (C) 2017 by The Author(s). Published by the International Association of Astacology. This article is distributed under the terms of the Creative Commons Attribution License (CC-BY 4.0), which permits unrestricted use, distribution, and reproduction in any medium, provided the original author and source are credited.

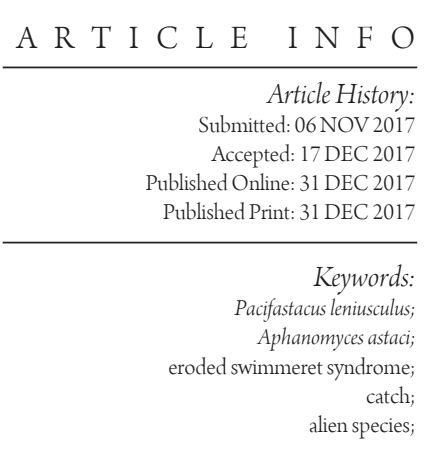

Peninsula) conditions, and that its populations are thriving despite A. astaci infection.

The Lake Saimaa region was traditionally a prime production region for wild stocks of the noble crayfish, Astacus astacus (Linné), but unfortunately, it was also the site where a mass mortality of noble crayfish was recorded for the first time in Finland due to a crayfish plague epidemic back in 1893 (Lehtonen 1975). From that time until the 1990s, the large lake was practically devoid of crayfish, containing only a very sparse noble crayfish population. During the 1980s and 1990s there was a popular trend of introducing signal crayfish, which resulted in signal crayfish being introduced to Lake Saimaa (Jussila et al. 2016), but this introduction was unlicensed (Ruokonen et al. 2017). The signal crayfish population was then slowly established and signal crayfish trapping started in the early 2000s. Among the catch, there was also the occassional rare noble crayfish until 2007, when a suspected acute crayfish plague epidemic eradicated all noble 
Table 1. Proportion of females with regenerated swimmerets caused by eroded swimmeret syndrome (ESS), the proportion of males with ESS-like trauma and the proportion of ESS-like trauma affected males with eroded gonopods, all expressed as percentages. Data was collected during the 2015 - 2017 field seasons and was pooled annually for each crayfisherman from all test trapping sites and expressed as mean $\pm \mathrm{SD}(\min -\max )$. Different supercripts on each line indicate statistically significant difference (t-test, $P<0.05)$.

\begin{tabular}{|c|c|c|c|}
\hline & 2015 & 2016 & 2017 \\
\hline Proportion of swimmeret regeneration in ESS affected females & $\begin{array}{l}7.9 \pm 7.8^{a} \\
(0-25.6)\end{array}$ & $\begin{array}{c}20.4 \pm 7.9^{b} \\
(5.9-33.3)\end{array}$ & $\begin{array}{c}25.6 \pm 10.1^{b} \\
(12.1-38.5)\end{array}$ \\
\hline Proportion of ESS-like trauma in males & $\begin{array}{r}1.1 \pm 1.0^{\mathrm{a}} \\
(0-2.8)\end{array}$ & $\begin{array}{c}4.7 \pm 1.9^{b} \\
(1.2-7.2)\end{array}$ & $\begin{array}{r}5.3 \pm 1.2^{b} \\
(4.1-7.9)\end{array}$ \\
\hline Proportion of gonopod trauma in ESS-like trauma affected males & $\begin{array}{r}7.5 \pm 11.6^{\mathrm{a}} \\
(0-30)\end{array}$ & $\begin{array}{r}48.3 \pm 13.7^{b} \\
(20-66.6)\end{array}$ & $\begin{array}{l}77.3 \pm 8.2^{c} \\
(66.7-80)\end{array}$ \\
\hline
\end{tabular}

crayfish and part of the signal crayfish population (Jussila et al. 2016). Since then, the signal crayfish population has been slowly recovering, but has been showing gross symptoms of a chronic crayfish plague infection (Jussila et al. 2016) in addition to the recently described eroded swimmeret syndrome (ESS) (Edsman et al. 2015). The crayfish production in Lake Saimaa has been moderate, normally a catch per unit effort (CPUE) between $1-2$ (i.e., crayfish per trap per night; Jussila et al. 2016).

Alien species, in this case alien crayfish, in addition to competing with native species utilizing the same niche, have also been shown in some cases to be maladapted to new environmental conditions or ecosystems (Sandström et al. 2014; Jussila et al. 2014a, 2016). It has been argued that introductions of alien species have sometimes been based on inflated expectations while ignoring science-based warnings (e.g., Bohman and Edsman 2011; Jussila et al. 2015a; Ruokonen et al. 2017), which further increases the risks of harmful introductions threatening native ecosystems and their associated biodiversity. The signal crayfish in Fennoscandia, and in Europe more broadly, appears to be one of these cases (Holdich et al. 2009; Jussila et al. 2015b). It would be beneficial to document these harmful situations, even after an official acknowledgement of the detrimental impact of alien species (EU Regulation 1143/2014), while in the case of the signal crayfish, attempts to eliminate future damage have also been suggested and partially implemented (e.g., Holdich et al. 1999; Peay et al. 2006).

This study is part of the Lake Saimaa signal crayfish survey (Jussila et al. 2016) and aims to improve awareness of $A$. astaci infection dynamics and its effects on the wild signal crayfish population. The alien signal crayfish has not adapted as well to Fennoscandian conditions as was initially expected when the introductions were initiated in the 1960s and 1970s (Ruokonen et al. 2017), leaving several aspects of their maladaptation still to be studied. The role of infection by $A$. astaci, together with additional opportunistic parasites, in controlling the dynamics of alien signal crayfish production in Fennoscandia requires a deeper understanding and Lake Saimaa presents a wonderful opportunity to study the relationships between A. astaci, Fusarium SC and signal crayfish in a wild setting.

\section{MATERIAL AND METHODS}

During a 9-year survey (2009-2017), we monitored the catch of three commercial crayfishermen in Lake Saimaa as part of a research and development project on the crayfisheries and crayfish handling and storage methods (e.g., Jussila et al. 2013b, 2014, 2016). In this paper, we present eroded swimmeret syndrome (ESS) related data covering the years 2013 - 2017 (males 2015 - 2017) along with a combination of ESS and A. astaci infectionrelated data from the period $2009-2016$.

Data was collected and catch measurements were made from a) three crayfishermen and b) two test sites per crayfisherman at four times per season (i.e., 3 crayfishermen $\times 2$ test sites $\times 4$ catching times during an eight-week period). The test trapping sites for each crayfisherman $(\mathrm{N}=2)$ were selected at the beginning of the survey and it was agreed that the crayfishermen would be trapping in these sites throughout the season as part of their trapping routine. This was to ensure that trapping pressure would be comparable within each site from one year to the next.

In total, 13,801 signal crayfish from the test trapping sites were measured, resulting in roughly 1,533 signal crayfish measurements annually. The following measurements were taken from the catch at each test site (the typical measurement and observation routine during surveys, although some of the information is not presented in this paper): carapace length $(\mathrm{CL}, \mathrm{mm})$; sex (male, female); claws (intact or not); glare gland development; gross symptoms of crayfish plague infection (rated as $0=$ no gross symptoms, $1=1-5$ melanised lesions and all appendages intact, $2=5+$ melanised lesions or lost appendages and melanisation); signs of eroded swimmeret syndrome (ESS) (rated as $0=$ healthy swimmerets, $1=$ melanised swimmerets, $2=1-7$ lost swimmerets and $3=$ all swimmerets lost) and specific additional notes on such things as carapace hardness, females carrying eggs or remains of eggs, unusual hemolymph color, swimmeret regeneration, etc. Swimmeret regeneration was identified as those swimmerets with healthy tissue but clearly smaller in size compared to what would be expected for the female in question (Jussila et al. 2016). We 
are discussing swimmeret regeneration here in order to describe the progress of the ESS recovery phase. Detailed notes on eroded swimmeret syndrome (ESS) (Edsman et al. 2015) have been taken since the 2013 annual survey.

The gross symptoms $A$. astaci infection were used as an indicator of infection, while some of the gross symptoms could have been caused by other pathogenic parasites, such as Fusarium SC (Makkonen et al. 2013). Having said that, we know from using qPCR analyses, that the prevalence of $A$. astaci infection among Lake Saimaa signal crayfish has been shown to be significantly higher (Strand et al. 2012) than that estimated just by observing gross symptoms of $A$. astaci infection during our surveys.

Due to presentation reasons, we have variably pooled the data from individual test trapping sites for ESS-related analyses for the period from 2013 - 2017 and for A. astaci infection related analyses for the period 2009 - 2016. Further details regarding data selection appear in the results section for each of the variables analysed.

We used MS-Excel for the data processing. The results are expressed as means with standard deviations when relevant, and a t-test was used to test for statistical significance.

\section{RESULTS}

An increasing proportion of swimmeret regeneration has been observed since 2015 among ESS affected females in Lake Saimaa (Table 1), with a rough tripling in the proportion of the females with regenerated swimmerets among those affected with ESS. The increase in the proportion of swimmeret regeneration among females showing ESS was statistically significant in the 2016 and 2017 surveys when compared to the 2015 survey. The minimum proportion has increased from $0 \%$ (year 2015) to $12.1 \%$ (year 2017).

We also observed that females with ESS had a delayed egg hatching rate and the only females still carrying eggs (either viable or dead) in August, were those females with ESS symptoms. They also had typcially lost a majority of their eggs, usually with less than 10 eggs remaining.

We also observed ESS-like trauma in male signal crayfish taken in the Lake Saimaa catch for the first time during the 2015 trapping season (Table 1), with roughly 1\% of them being affected. Since then, this proportion has increased to roughly $5 \%$, with a statistically significant increase in the proportion of ESSlike trauma appearing males during the 2016 and 2017 surveys when compared to the 2015 survey. Among these affected males, an increasing proportion of the observations seem to be directly affecting the male reproductive organs (i.e., gonopods), with a statistically significant increase from $7.5 \%$ in 2015 to $77.3 \%$ in 2017. It should be noted that the minimum proportion of gonopod affected males in an individual measurement increased from $0 \%$ (year 2015) to $66.7 \%$ (year 2017).

We observed a positive correlation between the proportion of signal crayfish females showing ESS and gross symptoms of

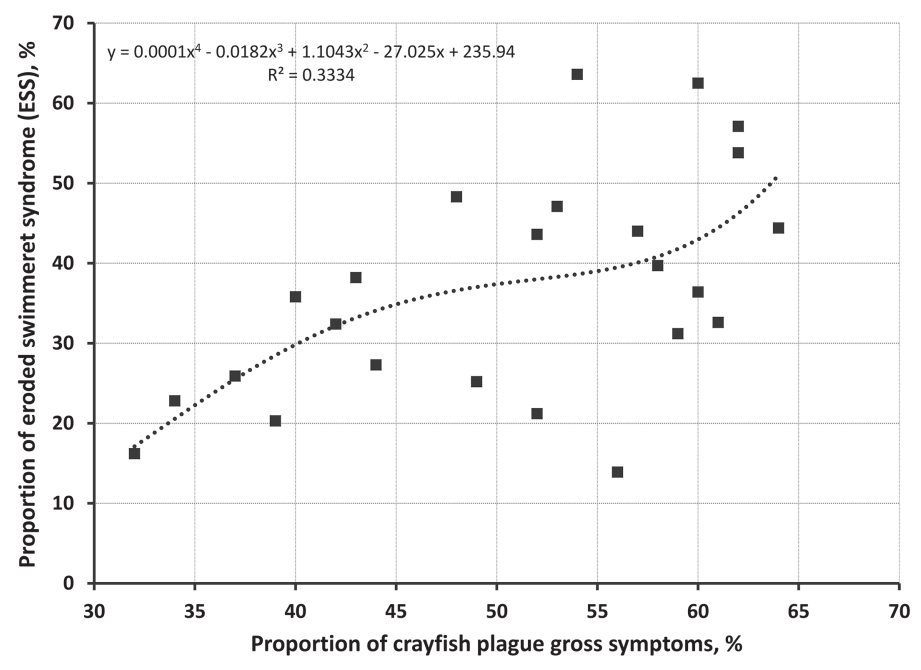

Figure 1. The relationship between the proportion of crayfish with eroded swimmeret syndrome (ESS) and those with gross symptoms of crayfish plague infection (\%) among the test site trap catches in Lake Saimaa signal crayfish populations during the 2013 - 2016 surveys. The data from each test trap site were pooled annually. The polynomial regression equation and its fit $\left(\mathrm{R}^{2}\right)$ are shown on the graph.

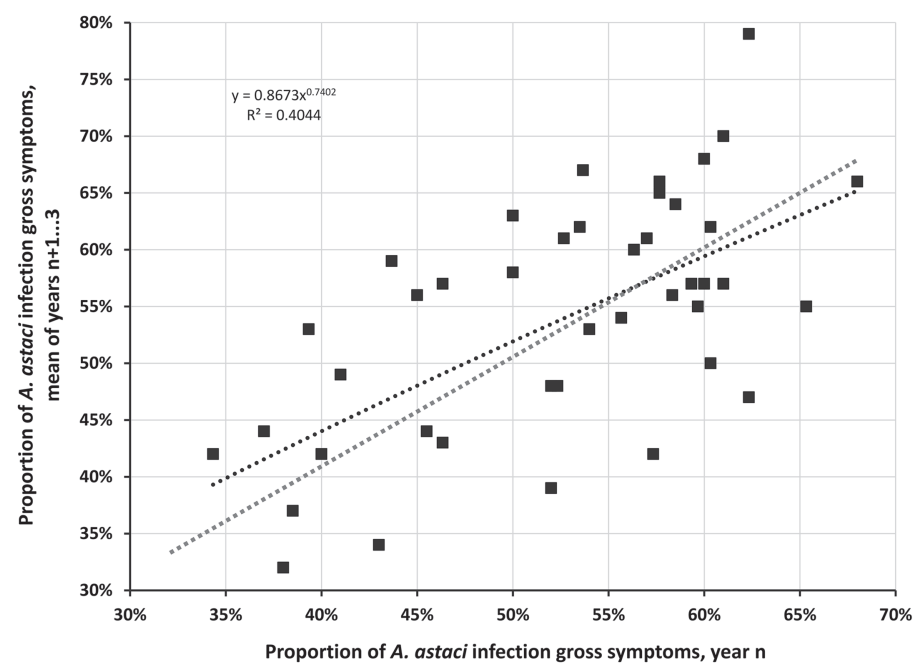

Figure 2. Relationship between gross symptoms of $A$. astaci infection between year $n$ and the mean of following three years (years $n+1 \ldots 3$ ). Data collected during 2009 - 2016 was pooled annually within each test trapping site. The best correlation fit $\left(\mathrm{R}^{2}\right)$ and equation are shown in the graph as black dotted line, the 1:1 line is a grey dotted line.

A. astaci infection in the test site catches (Figure 1). The best correlation fit was a polynomial regression, with an $\mathrm{R}^{2}=0.334$.

There was a positive correlation in the proportion of Lake Saimaa signal crayfish showing gross symptoms of crayfish plague within a test trapping site between year $\mathrm{n}$ and the mean of years $n+1 \ldots 3$ (Figure 2). The best correlation fit was a power trend, with the $\mathrm{R}^{2}=0.4044$. With a clear positive trend, there was still considerable variation in this relationship. The data (Figure 2) suggests that when the prevalence of $A$. astaci infection was low there was a short-term increase in prevalence, but when the prevalence of $A$. astaci infection was high, there was a 
short-term decrease in prevalance. This would result in a stable infection prevalence over the long-term because the population tends to increase or decrease towards an intermediate equilibrium prevalence of approximately $57 \%$.

\section{DISCUSSION}

Our study shows that a chronic $A$. astaci infection has persisted among Lake Saimaa signal crayfish, and this infection has remained at roughly similar levels throughout the 9-year survey period. Thus, the removal of infected signal crayfish individuals, or possible variable trapping pressure, did not have a significant effect on the prevalence of $A$. astaci infection, which appears to be equalizing at $57 \%$ over the long-term. Furthermore, we observed a biologically significant relationship between the prevalence of gross symptoms of $A$. astaci infection and eroded swimmeret syndrome (ESS) in the test trapping catch. This could indicate that these two conditions, or the pathogenic parasites causing these conditions, make the Lake Saimaa signal crayfish population more vulnerable, and co-occurence might confer some mutual benefit. Thus, it seems that the high prevalence of diseases and diseaselike symptoms in the Lake Saimaa signal crayfish population could significantly affect the production level of the signal crayfish population.

The removal of large sized signal crayfish could have affected the prevalence of the infection among the Lake Saimaa signal crayfish. The data in Figure 2 suggests that there could be a drive towards balanced infection prevalence, in this case approximately $57 \%$. It also seems that the prevalence of infection in Lake Saimaa signal crayfish would likely have increased if the larger size crayfish were not removed. Thus, this drive towards a balanced $57 \%$ infection rate could have been created by the commercial trapping. It remains to be studied whether the removal of larger sized crayfish, which are also infected, directly affects the prevalence of the infection in the lake.

Our study shows that the $A$. astaci infection in Lake Saimaa signal crayfish remains at a level typical of the subpopulation in question, although all commercial-sized crayfish (i.e., a heavily infected subpopulation (Strand et al. 2012; Jussila et al. 2016)), were removed annually from the test trapping sites. There was considerable variation observed in the data, but the overall trend was evident. The $\mathrm{R}^{2}$ for the fit was moderately high, but in our opinion, biologically meaningful (i.e., shows a trend that can be used to calculate future expectations for crayfish plague infection). It has been shown that the PsI-genotype of $A$. astaci that infects Lake Saimaa signal crayfish is rather virulent (Jussila et al. 2013a), and might be causing elevated levels of mortality among Lake Saimaa signal crayfish (e.g., Gren et al. 2009; Aydin et al. 2014; Sandström et al. 2014). The chronic A. astaci infection in Lake Saimaa signal crayfish could be affecting the production of commercial-sized crayfish, and thus might have a negative impact on commercial crayfish trapping.

We observed that the rate of $A$. astaci infection, based on visual gross symptoms, was positively correlated with ESS symptoms in the pooled data. This indicates that ESS could be directly affected by $A$. astaci infection, which has been previously speculated on by Edsman et al. (2015), while ESS itself is caused by Fusarium SC. It has been previously suggested that the Lake Saimaa signal crayfish may be maladapted to the Fennoscandian environmental conditions (Jussila et al. 2016), an assumption apparently supported by the prevalence of trauma and estimates of low production based on CPUE. These findings are alarming since one the main justifications for introducing the signal crayfish into Lake Saimaa was the expectation of high levels of commercial production (e.g., Bohman and Edsman 2011; Jussila et al. 2015a; Ruokonen et al. 2017), which now appears to be in jeopardy.

Female signal crayfish suffering from ESS are showing an increasing proportion of regenerated swimmerets (i.e., intact stumps), which seem to have totally lost their functionality in carrying the eggs during hatching (e.g., Jussila et al. 2016). If this speculation is valid, then even partially regenerated swimmerets would affect the reproductive effort and production capacity of Lake Saimaa signal crayfish. This statement is based on observations made during the surveys and it needs to be verified in future studies.

We also observed and documented damage to male swimmerets and gonopods, which could be named ESS-like trauma, since the symptoms are very similar to those seen in female signal crayfish (Edsman et al. 2015; Jussila et al. 2016). During the 2017 survey, an average of $5.3 \%$ of male signal crayfish showed ESS-like trauma and roughly $77 \%$ of those had their gonopods affected. It could be speculated that the traumatized gonopods would not function as reproductive organs, but since the males have 4 gonopods, this might not totally block their reproductive effort. It should be noted that the prevalence of males with ESS-like trauma has been increasing during the most recent 3-years of the survey (2015 2017), when observations of this condition were made. Again, this is another issue that requires further study.

Our current observations suggest that ESS delays egg hatching, in addition to causing significant egg loss. Hatching egg losses have been previously reported (Sandström et al. 2014) with a loss of one swimmeret causing $12.5 \%$ loss. We have also reported earlier that there could be a delay in egg hatching due to ESS (Jussila et al. 2016), which can now be verified. Summer 2017 was rather cold with low water temperatures, which could have added to delays in hatching, but, as reported previously, ESS could have a significant role in delaying egg hatching. As a result, we could speculate that stage 2 ESS might cause a complete loss of crayfish progeny for females with ESS, due to direct egg loss and late hatching of the juveniles, which then would not survive their first winter. This possible aspect of multiple causes compounding to cause reproductive failure would be interesting, and from the point of view of alien species adaptation, is an evolutionarily relevant study angle.

The widely reported phenomena of the collapses of wild signal crayfish stocks (Edgerton et al. 2004; Jussila et al. 2014a, 2014b, 2016; Sandström et al. 2014) is a topic which should be investigated in the future. The first indications of signal crayfish maladaptation under Fennoscandian conditions were reported from Sweden (Gren et al. 2009; Sandström et al. 2014), while there are now increasing number of reports also from Finland (Jussila et 
al. 2014a, 2014b, 2016), with the most recent coming from Lake Pyhäjärvi (Tampere) in the summer of 2017. It appears that parts of Lake Pyhäjärvi have all but lost a productive population (Kolari 2017, personal communication).

We have shown that ESS is associated with female crayfish suffering from direct and secondary trauma caused by an $\mathrm{A}$. astaci infection, and thus we theorize that signal crayfish adaptation to the Fennoscandian conditions is still pending. We have also verified our previous initial finding that male signal crayfish can also be affected by ESS, possibly by traumatizing their reproductive organs, the gonopods. These findings, together with several reports on Fennoscandian signal crayfish population crashes, open avenues for further studies on factors affecting alien signal crayfish wellbeing in Fennoscandian waters.

\section{ACKNOWLEDGMENTS}

The study was supported by LIFE12 INF/FI/233 funding and the Fisheries Compensation Funds from the Southeastern ELY Center.

\section{LITERATURE CITED}

Aydin H, Kokкo H and Makkonen J (2014). The signal crayfish is vulnerable to both the As and the PsI-isolates of the crayfish plague. Knowledge and Management of Aquatic Ecosystems 413: 03.

Bohman P, Nordwall F and Edsman L (2006). The effect of large-scale introduction of signal crayfish on the spread of crayfish plague in Sweden. Bulletin Français de la Pêche et de la Pisciculture 380-381: 1291-1302.

Bohman P and Edsman L (2011). Status, management and conservation of crayfish in Sweden: results and the way forward. Freshwater Crayfish 18(1): 19-26.

Edgerton BF, Henttonen P, Jussila J, Mannonen A, Paasonen P, Taugbøl T, Edsman L and Souty-Grosset C (2004). Understanding the causes of disease in European freshwater crayfish. Conservation Biology 18(6): 1466-1474.

Edsman L, Nyström P, SAndström A, Stenkerg M, Kokko H, Tititinen V, Makkonen J and Jussila J (2015). Eroded swimmeret syndrome in female crayfish Pacifastacus leniusculus associated with Aphanomyces astaci and Fusarium spp. infections. Diseases of Aquatic Organisms 112(3): 219228.

Gren I-M, IsaAcs L and Carlson M (2009). Costs of alien invasive species in Sweden. Ambio 38(3): 135-140.

Holdich DM, Gydemo R and Rogers WD (1999). A review of possible methods for controlling alien crayfish populations. Pp. 245-270, In: Crustacean Issues 11. Crayfish in Europe as Alien Species. Gherardi F and Holdich DM (eds.). A.A. Balkema. Rotterdam, Netherlands.

Holdich DM, Reynolds JD, Souty-Grosset C and Sibley PJ (2009). A review of the ever increasing threat to European crayfish from non-indigenous crayfish species. Knowledge and Management of Aquatic Ecosystems 394-395: 11.

Jussila J, Kokko H, Kortet R and MaKkonen J (2013a). Aphanomyces astaci PsI-genotype isolates from different Finnish signal crayfish stocks show variation in their virulence but still kill fast. Knowledge and Management of Aquatic Ecosystems 411: 10.

Jussila J, Titininen V, Fotedar R and Kokko H (2013b ). A simple and efficient cooling method for post-harvest transport of the commercial crayfish catch. Freshwater Crayfish 19(1): 15-19.

Jussila J, Makkonen J, Kokko H and MäKinen P (2014a). Numerous population crashes of wild signal crayfish (Pacifastacus leniusculus) in Southern Finland. Freshwater Crayfish 19(1): 73-79.

Jussila J, Makkonen J, Vainikka A, Kortet R and Kokko H (2014b). Crayfish plague dilemma: how to be a courteous killer? Boreal Environment Research 19(3): 235-244.

Jussila J, Maguire I, Kokko H, Kortet R and Makkonen J (2015a). Chaos and adaptation in the host-pathogen relationship in relation to the conservation: the case of the crayfish plague and the noble crayfish. Pp. 246-274, In: Freshwater Crayfish: Global Overview. Kawai T, Faulker Z and Scholtz G (eds.). Science Publishers, USA.

Jussila J, Vrezec A, Makkonen J, Kortet R and Kokko H (2015b). Invasive crayfish and their invasive diseases in Europe with the focus on the virulence evolution of the crayfish plague. Pp. 183-211, In: Biological Invasions in Changing Ecosystems. Vectors, Ecological Impacts, Management and Predictions. Canning-Clode J (ed.). De Gruyter Ltd, Warsaw, Poland.

Jussila J, Tittinen V, Edsman L, Kokko H and Fotedar R (2016). Signal crayfish in Lake Saimaa could be maladapted to the local conditions due to Aphanomyces astaci infection: A seven-year study. Freshwater Crayfish 22(1): 53-60.

Kolari I (2015). Pirkanmaan kalatalouskeskus, Tampere, Finland. Personal communication.

Lehtonen JUE (1975). Kansanomainen ravustus ja rapujen hyväksikäyttö Suomessa. (English: Common catching habits and utilisation of crayfish in Finland). Tapiola, Suomi-Finland: Oy Weilin+Göös Ab. [In Finnish].

Makkonen J, Jussila J, Koistinen L, Paaver T, Hurt M and Kокко H (2013). Fusarium avenaceum causes burn spot disease syndrome in noble crayfish (Astacus astacus). Journal of Invertebrate Pathology 113(2): 184-190.

NyLund V AND Westman K (2000). The prevalence of crayfish plague (Aphanomyces astaci) in two signal crayfish (Pacifastacus leniusculus) populations in Finland. Journal of Crustacean Biology 20(4): 777-785.

Peay S, Hiley PD, Collen P and Martin I (2006). Biocide treatment of ponds in Scotland to eradicate signal crayfish. 
Bulletin Français de la Pêche et de la Pisciculture 380-381: 1363-1379.

Ruokonen T, Suövik R, ERKamo E, Tulonen J, Ercoli F, KoKko H AND Jussila J (2017). Introduced alien signal crayfish (Pacifastacus leniusculus) in Finland - uncontrollable expansion despite numerous management strategies. Knowledge and Management of Aquatic Ecosystems. Submitted.

Sahlin U, Smith HG, Edsman L and Bengtsson G (2010). Time to establishment success for introduced signal crayfish in Sweden - a statistical evaluation when success is partially known. Journal of Applied Ecology 47: 1044-1052.

Sandström A, Andersson M, Asp A, Bohman P, Edsman L, Engdahl F, Nyström P, Stenberg M, Hertonsson P, VRÅlstad T AND GRANÉLI W (2014). Population collapses in introduced non-indegenous crayfish. Biological Invasions 16(9): 1961-1977.

Strand D, Jussila J, ViljamaA-Dirks S, Kokko H, Makkonen J, Holst-Jensen A, Viljugrein H And Vrålstad T (2012). Monitoring the spore dynamics of Aphanomyces astaci in the ambient water of latent carrier crayfish. Veterinary Microbiology 160(1-2): 99-107.

ThÖRnQVIST P-O AND SÖDERHÄLL K (1993). Psorospermium haeckeli and its interaction with the crayfish defence system. Aquaculture 117(3-4): 205-213. 